

\section{DISCLAIMER}

This report was prepared as an account of work sponsored by an agency of the United States Government. Neither the United States Government nor any agency Thereof, nor any of their employees, makes any warranty, express or implied, or assumes any legal liability or responsibility for the accuracy, completeness, or usefulness of any information, apparatus, product, or process disclosed, or represents that its use would not infringe privately owned rights. Reference herein to any specific commercial product, process, or service by trade name, trademark, manufacturer, or otherwise does not necessarily constitute or imply its endorsement, recommendation, or favoring by the United States Government or any agency thereof. The views and opinions of authors expressed herein do not necessarily state or reflect those of the United States Government or any agency thereof. 


\section{DISCLAIMER}

Portions of this document may be illegible in electronic image products. Images are produced from the best available original document. 
Reference to a company or product name does not imply approval or recommendation of the product by Union Carbide Corporation or the Department of Energy to the exclusion of others that may meet specifications.

Printed in the United States of America. Available from National Technical Information Service

U.S. Department of Commerce

5285 Port Royal Road, Springfield, Virginia 22161

Price: Printed Copy $\$ 4.50$, Microfiche $\$ 3.00$

This report was prepared as an account of work sponsored by an agency of the United States Government. Neither the United States Government nor any agency thereof, nor any of their employees, nor any of their contractors, subcontractors, or their employees, makes any warranty, express or implied, nor assumes any legal liability or responsibility for any third party's use or the results of such use of any information, apparatus, product or process disclosed in this report, nor represents that its use by such third party would not infringe privately owned rights. 
Distribution Category: UC-38

$Y-2138$

Date of Issue: September 19, 1978

\title{
ELECTRON-BEAM BRAZE WELDING OF BERYLLIUM
}

\author{
M. A. Perkins \\ Metallurgy Department \\ $Y-12$ Development Division
}

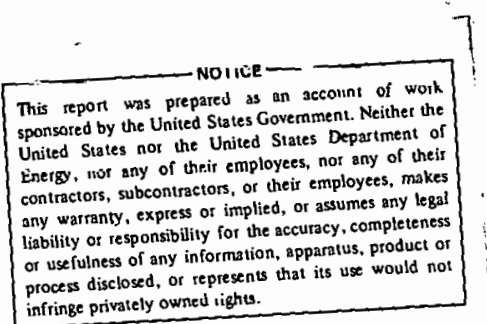

Oak Ridge $Y-12$ Plant

P. O. Box Y. Oak Ridge, Tennessee 37830

Prepared for the Department of Energy

Under US Government Contract W-7405-eng-26 


\begin{abstract}
Electron-beam braze welds were made in beryllium by using less than the recommended amount of aluminum filler metal. The welds exhibited a tendency to form microcracks prior to the termination of solidification; however, these microcracks were healed by the backfilling action of the aluminum/beryllium eutectic present in the fusion zone. Adverse effects attributable to the prior microcracking condition were not found.
\end{abstract}


CONTENTS

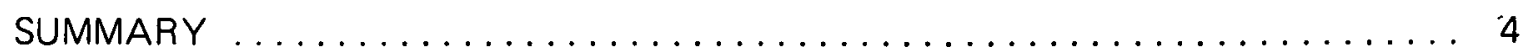

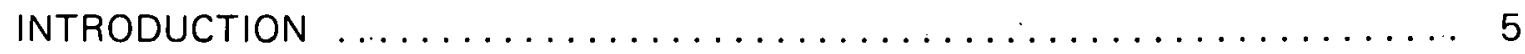

ELECTRON-BEAM BRAZE WELDING OF BERYLLIUM .............. 6

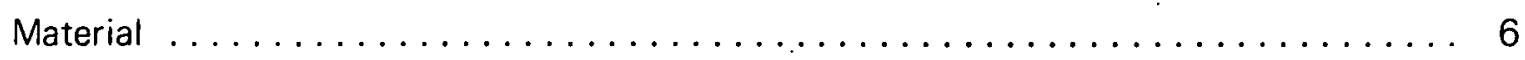

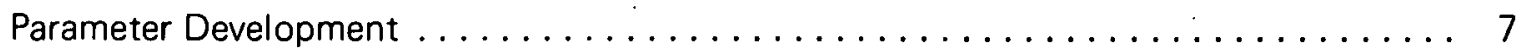

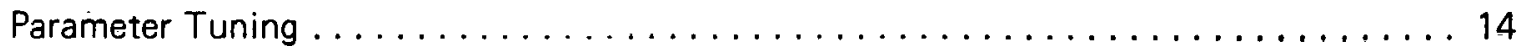

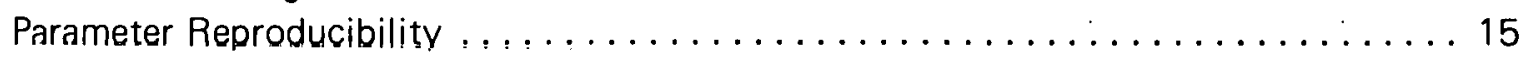

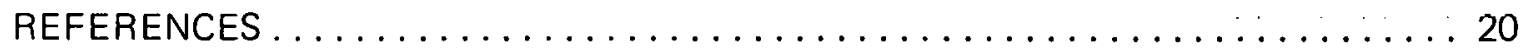

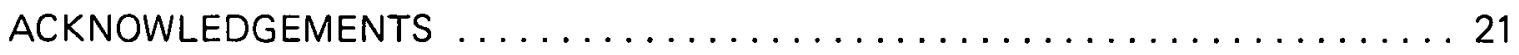




\section{SUMMARY}

The parameters which were developed for making a 2.54-mm-penetration, electron-beam braze weld in beryllium produced consistent and predictable results. While an aluminum content less than that recommended for this depth of penetration did result in the presence of prior microcracking, (a) no adverse effects on the structural performance of the welds were detected. The presence of the prior microcracking means that caution should be used when making electron-beam braze welds containing less than $30 \mathrm{wt} \%$ aluminum, because part of the conditions for microcracking exist.

(a) The term "prior microcracking" is used because all microcracking that was detected by optical microscopy appeared to be healed by backfilling by the aluminum/beryllium eutectic prior to the termination of solidification. 


\section{INTRODUCTION}

The fusion welding of beryllium is characterized by a pronounced tendency to hot crack. Aluminum is present in beryllium as an impurity, and it is generally agreed that hot cracking is due to small pockets of the aluminum/beryllium eutectic which are forced to the grain boundaries during solidification. Upon application of sufficient strain, the solid bridges which separate these eutectic pockets rupture, allowing the low-melting liquid to be drawn into the resulting crack by capillary action. When the strain is sufficiently large, the capillary forces are too small and the available eutectic too limited to fill the crack; thus, an open crack results. This theory was developed by Passmore ${ }^{1}$ and is in agreement with the generalized theories of hot cracking. $2-6$

Several methods have been used to produce sound, crack-free welds in beryllium. One of the most successful is the electron-beam braze-welding technique. ${ }^{7-9}$ Braze welding, using an aluminum filler metal, produces a fusion-zone microstructure consisting of beryllium dendrites surrounded by a ductile aluminum/beryllium matrix. This matrix increases the joint ductility and, thus, reduces the cracking susceptibility. Additionally, the presence of a large amount of the aluminum/beryllium eutectic overpowers the hot-cracking tendency by providing excess eutectic for the backfilling of hot cracks, if and when they occur.

For the electron-beam braze-welding technique, best results are obtained when the composition of the fusion zone is approximately $30 \mathrm{wt} \%$ aluminum. ${ }^{10}$ Aluminum is introduced into the weld joint by using a thin shim, and $30 \mathrm{wt} \%$ translates to the use of about $0.15 \mathrm{~mm}$ of aluminum shim width for each $1.02 \mathrm{~mm}$ of penetration. In this work, fairly deep penetration welds were required in beryllium, so it was decided to evaluate the effects of using a reduced amount of aluminum. The goal of this work, performed at the Oak Ridge Y-12 Plant, (b) was to develop a $2.54-\mathrm{mm}$ penetration weld with only a 0.25-mm-wide aluminum shim.

(b) Operated by the Union Carbide Corporation's Nuclear Division for the Department of Energy. 


\section{ELECTRON-BEAM BRAZE WELDING OF BERYLLIUM}

\section{MATERIAL}

The material for this study was purchased from Brush Wellman, Inc and prepared by Rockwell International. (c) The material was purchased to Beryllium Specification RM-251520 (d) (see Table 1) with two exceptions-BeO $<0.9 \%$ and $\mathrm{Al}<0.04 \%$, both lower

Table 1

BERYLLIUM SPECIFICATION RM-251520

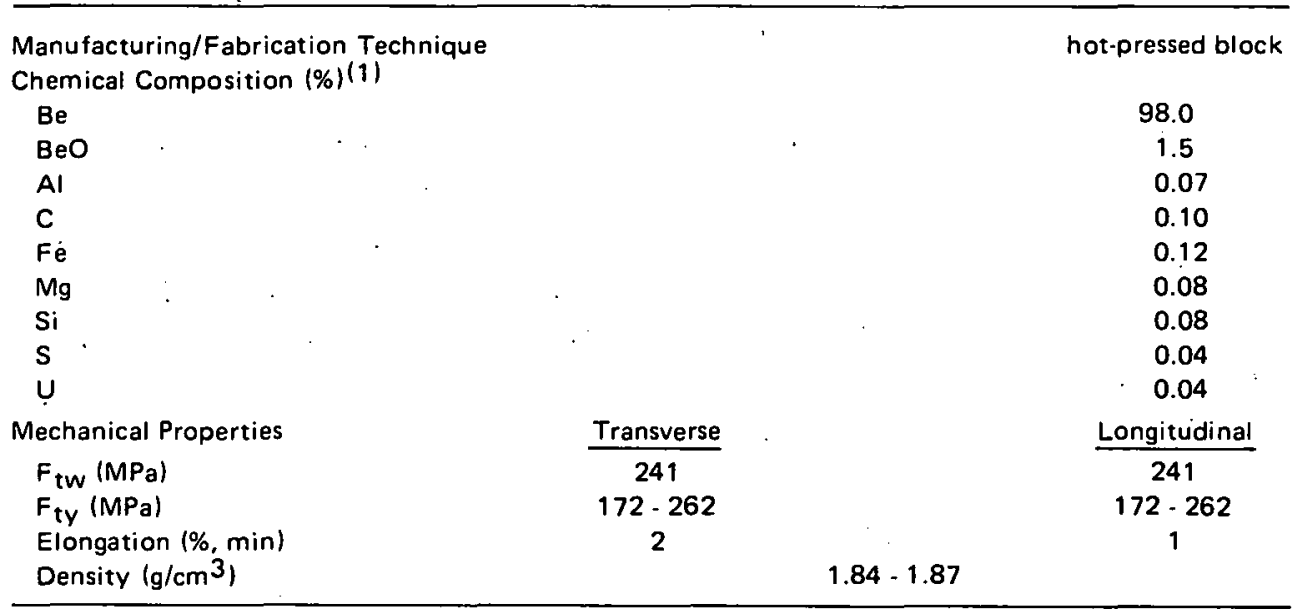

(1) All are maximum values except Be which is a minimum value.

than the specification maximum. ${ }^{11}$ The hot-pressed material was machined into eight sets of large-diameter rings $(420 \mathrm{~mm})$-four each of the two joint designs depicted in Figure 1 . Large-diameter rings were chosen for study because of the relative ease of obtaining welding and distortion data. The rings were machined such that the longitudinal direction of the hot-pressed block from which the rings were machined was transverse to the weld joint.

After machining, $0.25 \mathrm{~mm}$ of Type $1100-0$ aluminum was vapor deposited on the joints, as depicted in Figure 1. The tolerance of the vapor-deposited aluminum was $\pm 0.03 \mathrm{~mm}$, or approximately $\pm 10 \%$ of the thickness. Vapor deposition is the recommended technique for introducing the aluminum into the weld joint because the slight bonding of the aluminum to the beryllium holds the aluminum in place. Use of aluminum shims has been also investigated by others; however, besides the difficulty encountered in fabricating large-diameter, thin aluminum shims, the electron beam cuts the shim as the welding proceeds. When cut, there is a tendency for the shim to occasionally "pop" out of the joint and results in an area being welded with no aluminum. These areas are then very sensitive to cracking, as would be expected.

(c) Atomics International Division, Rocky Flats Plant, Golden, Colorado.

(d) This specification was prepared by the Lawrence Livermore Laboratory. 


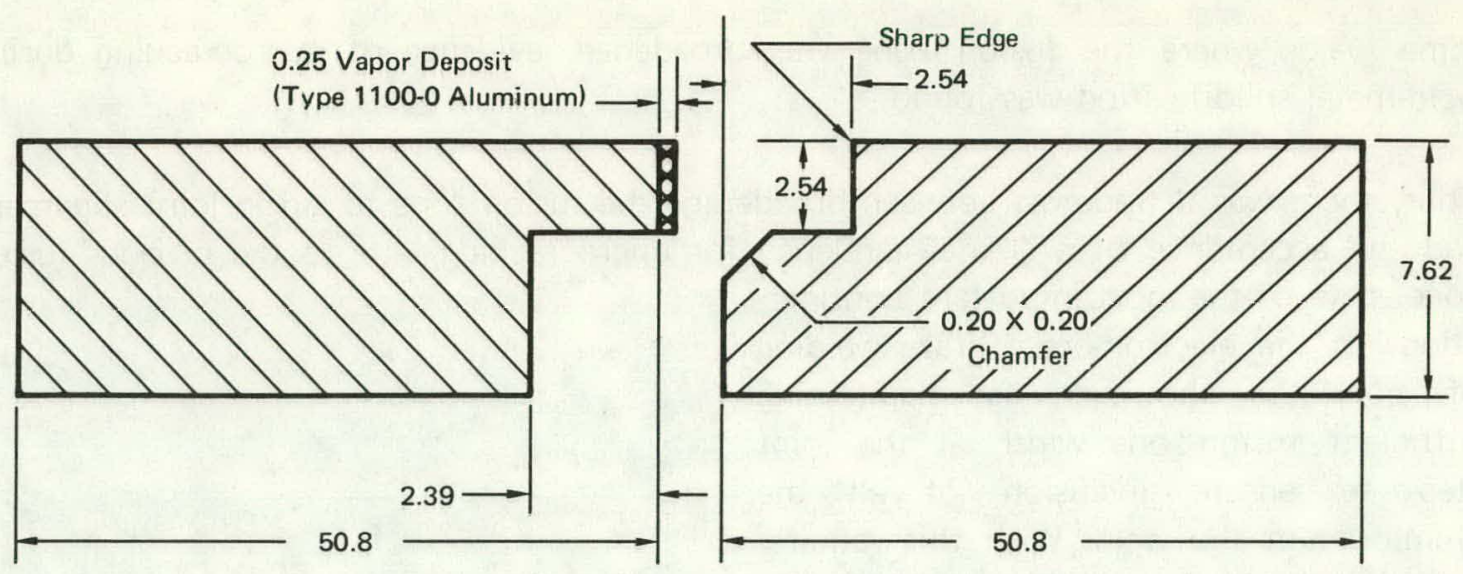

(a) Joint Design 1 .

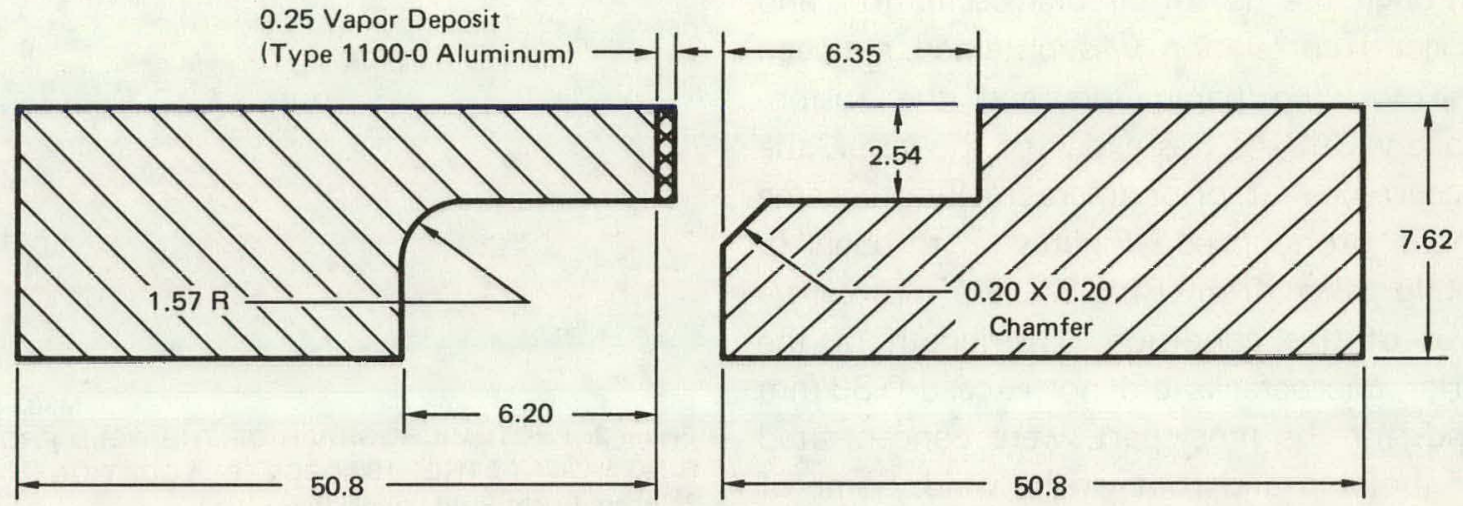

(b) Joint Design 2.

Figure 1. TWO JOINT DESIGNS FOR THE ELECTRON-BEAM BRAZE-WELDING EVALUATION. (AII Dimensions are in $\mathrm{mm}$ )

\section{PARAMETER DEVELOPMENT}

Three sets of rings (Rings $1 \mathrm{~A}, 2 \mathrm{~A}$, and $3 \mathrm{~A}$ ), incorporating Joint Design 1, Figure 1, were used to develop the electron-beam welding parameters. All welding was performed on two 7.5-kW, high-voltage, Hamilton Standard electron-beam welders.

Previous experience with electron-beam braze welding of beryllium has indicated that best results are normally obtained at moderate voltage levels $(80-110 \mathrm{kV})$ and relatively slow welding speeds $(8.47-12.70 \mathrm{~mm} / \mathrm{sec})$; therefore, this range of parameters was used on the first set of rings to achieve the minimum $2.54-\mathrm{mm}$ penetration required. Evaluation of Ring $1 \mathrm{~A}$ revealed four significant trends: (1) welds made with a sharply focused beam were generally very narrow, and some difficulties were encountered with joint alignment; (2) use of a defocused beam to broaden the fusion zone and thus improve joint alignment resulted in very rough weld-bead surfaces; (3) circular oscillation was very successful in broadening the fusion zone and maintaining a relatively smooth weld-bead surface; (4) in 
some welds where the fusion zone was broadened, evidence of microcracking during weld-metal solidification was found.

Thus, there was a trade off between broadening the fusion zone to aid in joint alignment and the acceptance of a greater tendency for microcracking, due to the broader fusion zone. One of the most important considerations in the electron-beam braze welding of beryllium, however, is maintaining sufficient fusion-zone width at the joint step to ensure inclusion of all the aluminum in the weld. With this requirement in mind, Ring 2A was welded with parameters intended to further broaden the fusion zone. This goal was realized through the use of circular oscillation, and a good correlation was obtained between the welding parameters and the fusionzone width. As was expected, however, the occurrence of prior microcracking became more pronounced. Figures 2 through 6, while taken from Ring $3 A$, are representative of this condition. The length of the prior microcracks did not exceed $0.38 \mathrm{~mm}$ and, for the most part, were concentrated at the step and root of the weld. Some of the prior microcracking occurring at the
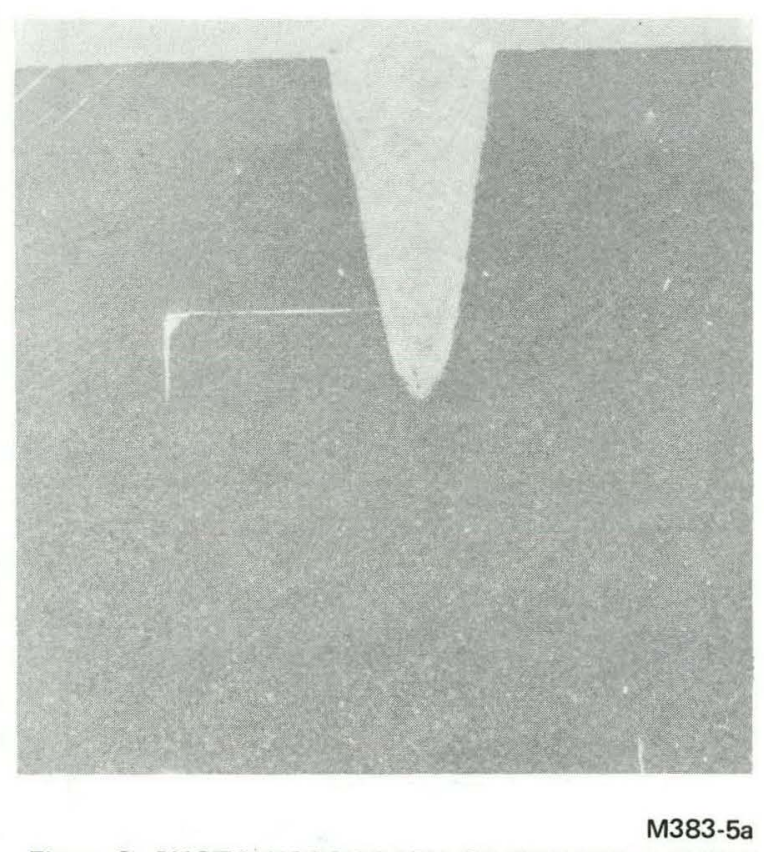

Figure 2. PHOTOMICROGRAPH OF THE WELD FROM RING 3A, AT THE 180-DEGREE LOCATION. (As Polished; Bright Field Illumination; 10X) weld root and along the sides of the fusion zone, where it extends into the heat-affected zone, is probably due to grain-boundary liquation as opposed to microcracking and subsequent healing.

Evaluation of numerous prior microcracks and liquated grain boundaries with the scanning electron microscope (SEM) provided the further evidence of healing by the aluminum/beryllium eutectic. Figure 7 is representative of these evaluations. The series of SM photographs clearly define the aluminum/beryllium eutectic matrix in the fusion zone; and, in this case, provide evidence that the liquated grain boundary is filled by the aluminum/beryllium eutectic.

The presence of prior microcracks indicated that welds in this range of penetration and aluminum content were borderline. If these welds were subjected to higher strain levels, cracking could occur. The aluminum content of these welds ranged from $20-27$ wt \%, which is below the $30 \mathrm{wt} \%$ that Hicken and Sample ${ }^{10}$ found was necessary to produce sound, crack-free, high-strength joints. Unfortunately, attempts to measure the aluminum content of the fusion zones, both by the electron microprobe and physical measurement, were not accurate enough to correlate the aluminum concentration with the occurrence or degree of prior microcracking. Results of tensile specimens tested from welds later in 


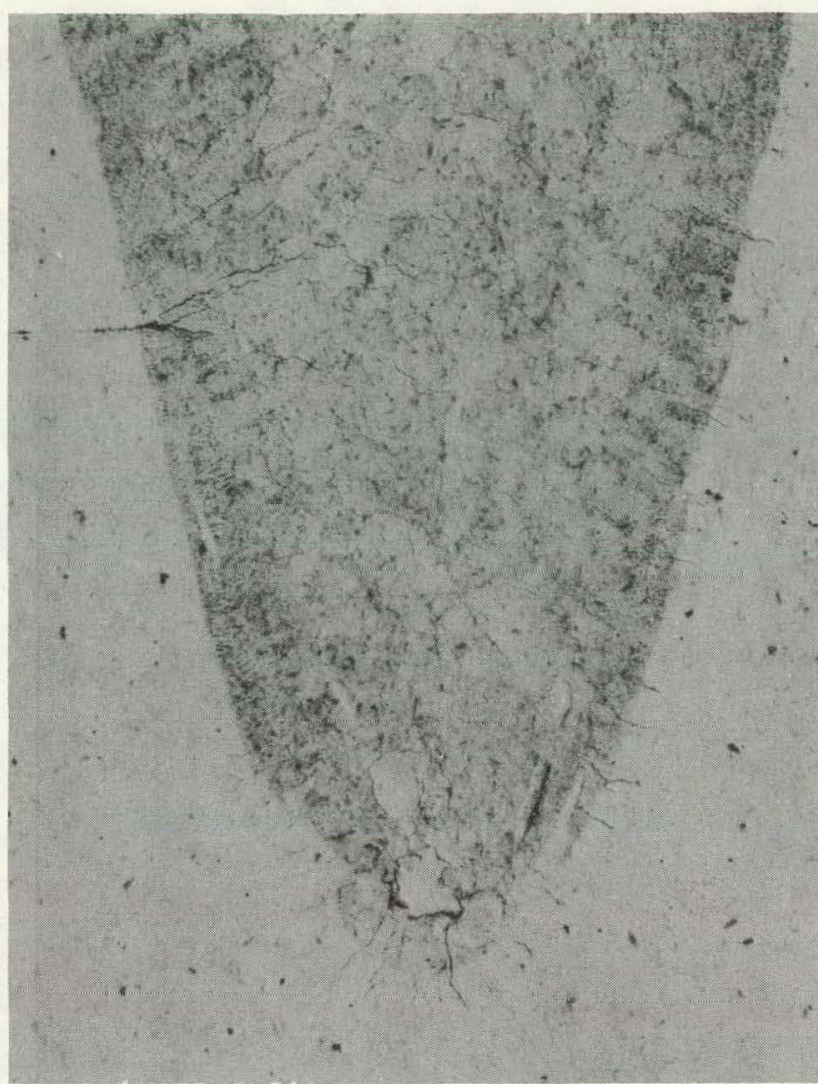

M383-5b

Figure 3. PHOTOMICROGRAPH OF THE WELD FROM RING 3A, AT THE 180-DEGREE LOCATION. (The Prior Microcracking is Very Evident at the Step and Root of the Weld; As Polished; Bright Field Illumination; 75X)

the test sequence indicated that the presence of prior microcracks did not have a detrimental effect on the structural performance of the beryllium. Additionally, radiographs of these welds failed to reveal any linear discontinuities.

The results of Rings $1 \mathrm{~A}$ and $2 \mathrm{~A}$ yielded a set of desirable parameters:

$\begin{array}{ll}\text { Voltage }(k V) & 110.0 \\ \text { Current }(m A) & 11.0\end{array}$

Travel Speed $(\mathrm{mm} / \mathrm{sec}) \quad 8.1$

Focus sharp at the surface

Beam Deflection X-10 Div, Y-10 Div (10-division circle)

Ream Oscillation (cps) 999 
As a note of explanation, the beam deflection (circle size) was established and measured at $2.0 \mathrm{~mA}$ and $200 \mathrm{cps}$ because the circle is well defined visually. These conditions, along

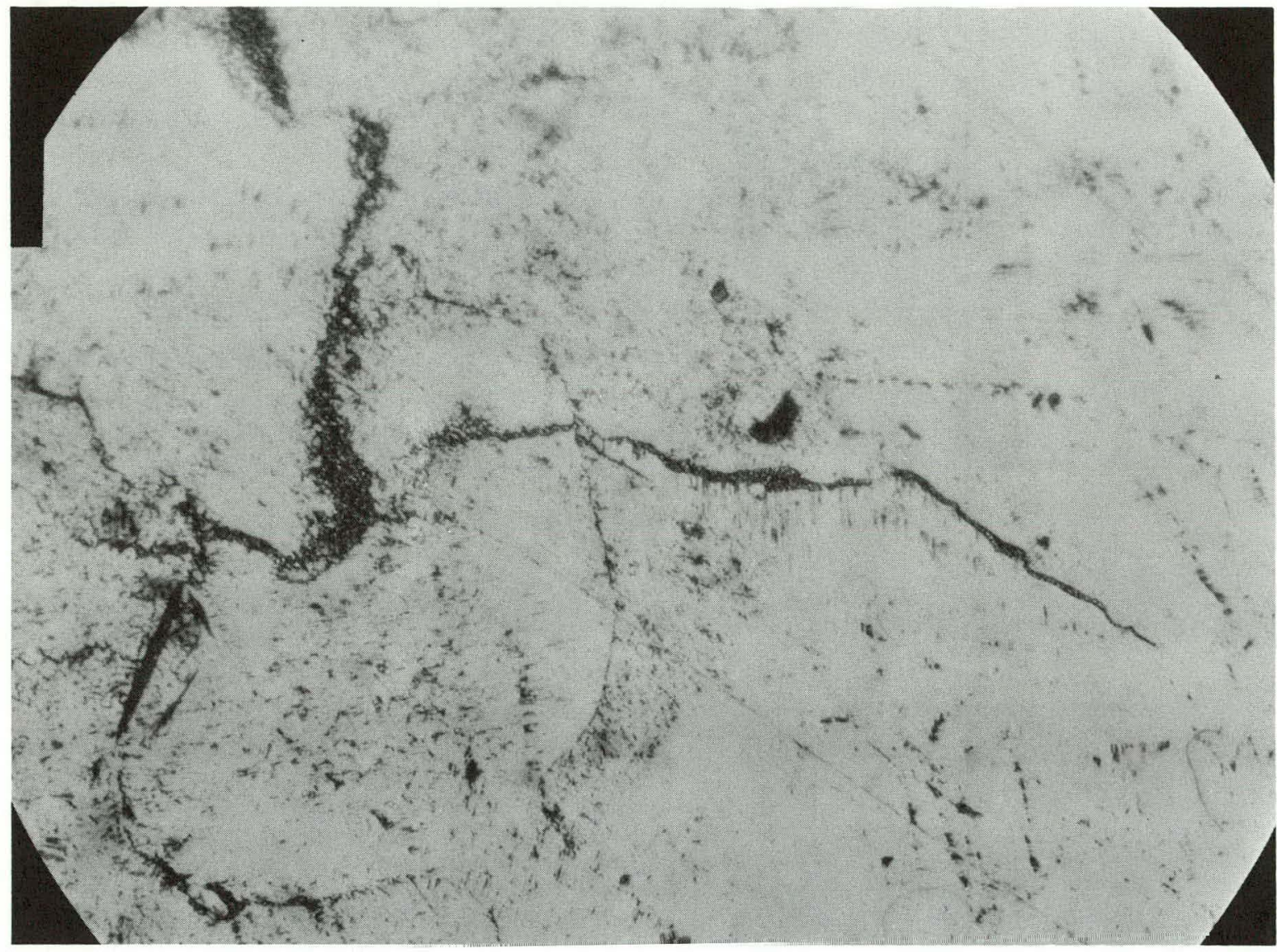

M383-5c

Figure 4. PHOTOMICROGRAPH OF THE ROOT AREA SHOWN IN FIGURE 3. (Microcracks do Appear to have been Backfilled with Al/Be Eutectic; As Polished; Bright Field Illumination; 750X)

with the working height in the welding chamber, gave a 0.95-mm-diameter circle. At the power levels and cps used for welding, the circle is smaller and too bright to define its size accurately.

The parameters developed from Rings $1 \mathrm{~A}$ and $2 \mathrm{~A}$ were then used to weld Ring $3 \mathrm{~A}$. The average penetration for Ring $3 A$ was $3.45 \mathrm{~mm}$, with a standard deviation of $\pm 0.08 \mathrm{~mm}$; while the aluminum content of the fusion zone averaged $22.9 \mathrm{wt} \%$, with a standard deviation of $\pm 0.33 \mathrm{wt} \%$. These results were very consistent. It should again be pointed out that what may appear to be excess penetration, when only a depth of $2.54 \mathrm{~mm}$ was required, was necessary to maintain sufficient fusion-zone width to ensure that all the aluminum was included in the weld. Figures 2 through 6 present views which are representative of this weld and depict the prior microcracking condition prevalent in these welds. 


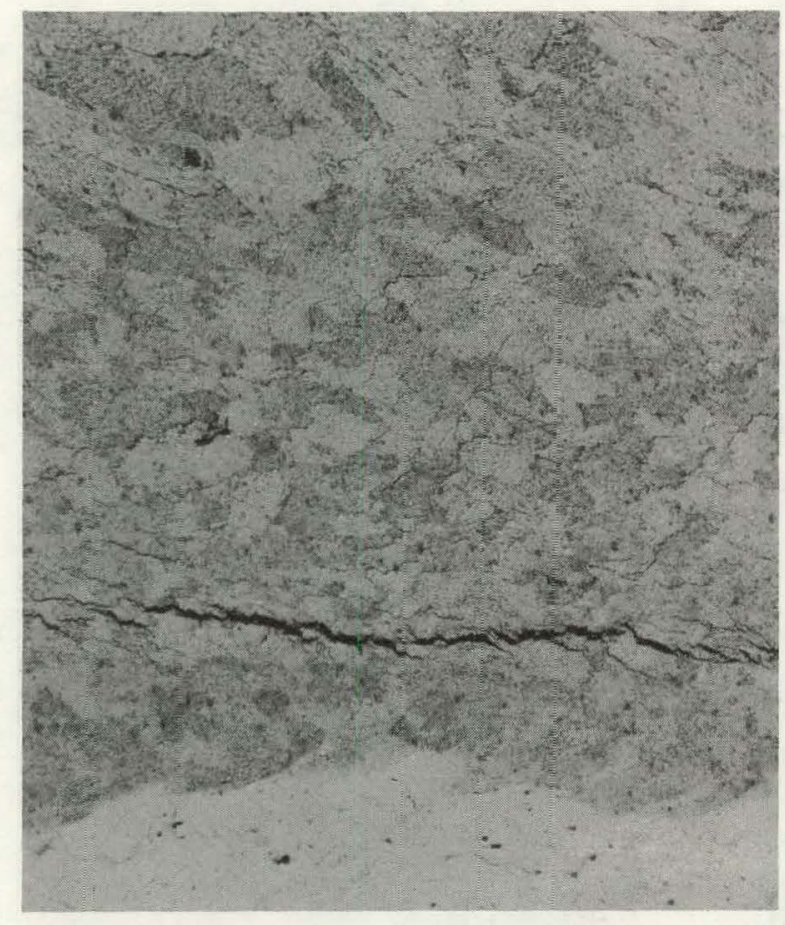

M383-6a

Figure 5. PHOTOMICROGRAPH OF THE LONGITUDINAL SECTION OF THE WWELD FROM RING 3A AT THE 180-DEGREE LOCATION. (Prior Microcracking in the Step Area is Very Evident; As Polished; Bright Field Illumination; $75 \times)$

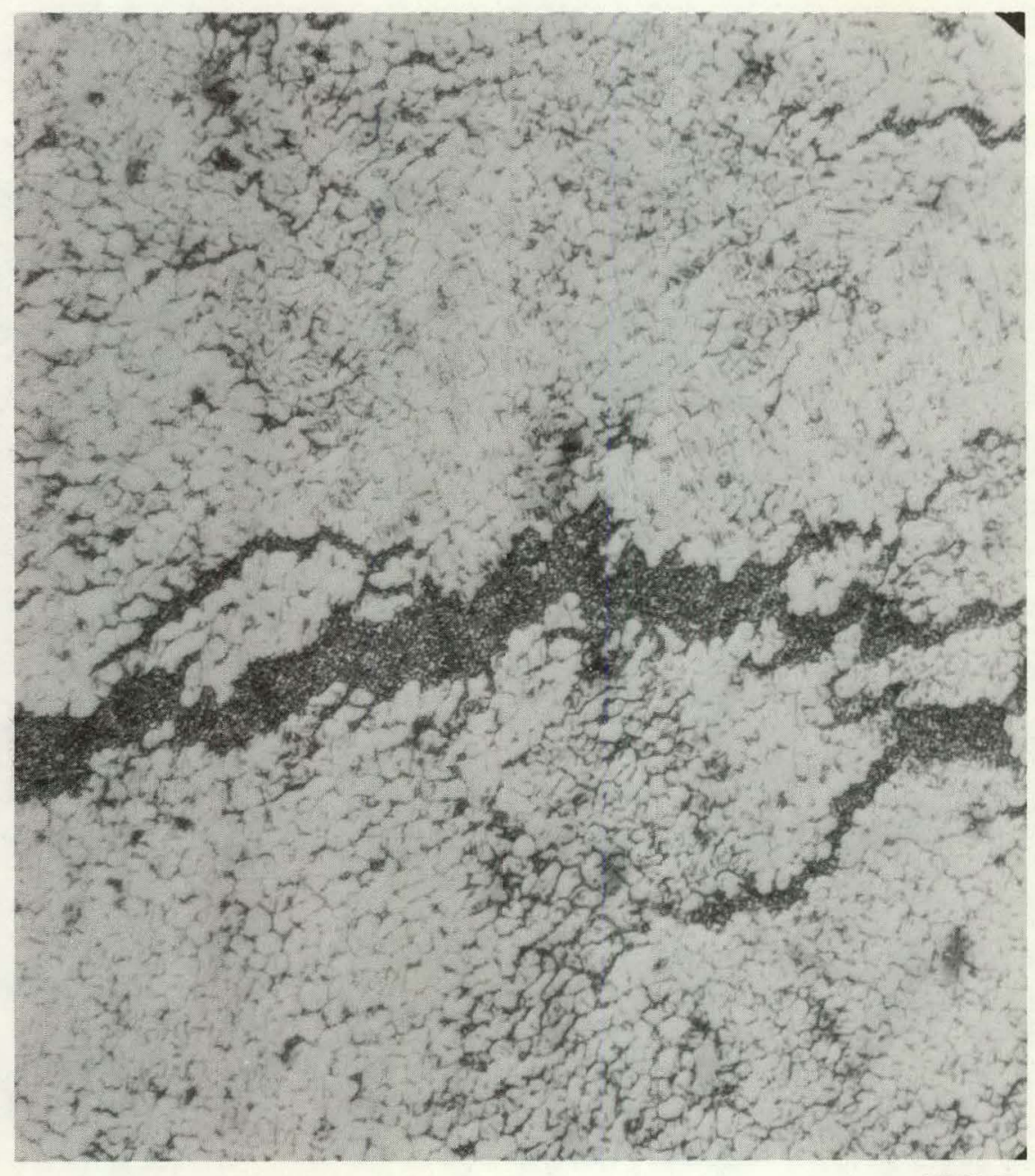

M383-6b

Figure 6. PHOTOMICROGRAPH OF THE STEP AREA SHOWN IN FIGURE 5. (Again, Microcracks have been Backfilled with $\mathrm{Al} / \mathrm{Be}$ Eutectic; As Polished; Bright Field Illumination; $750 \mathrm{X}$ ) 


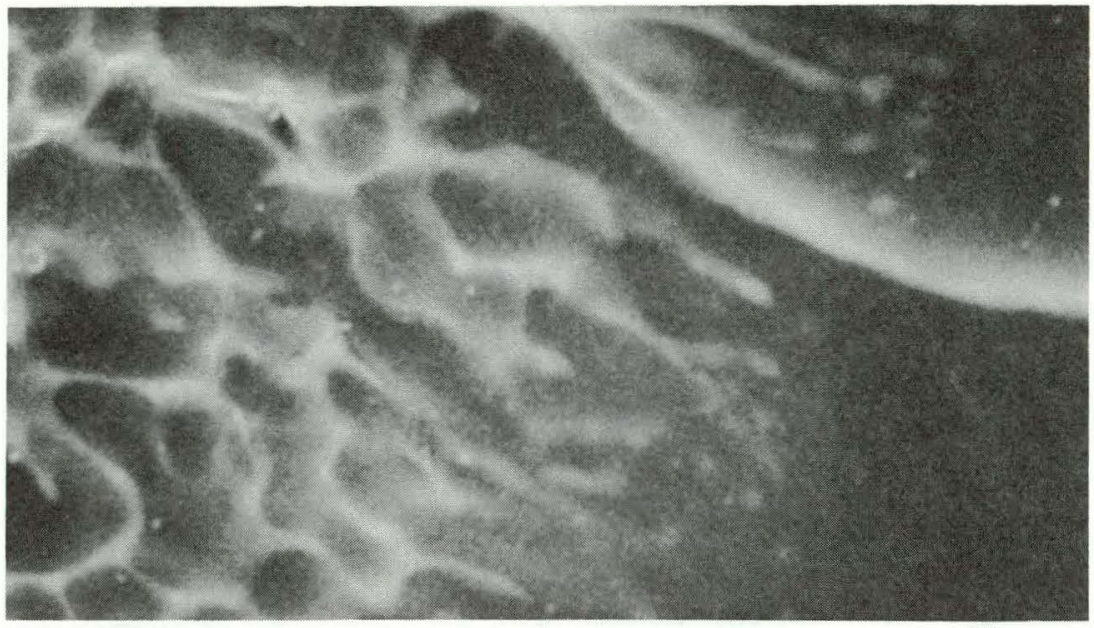

(a) At $3000 \mathrm{x}$.

SM-63739

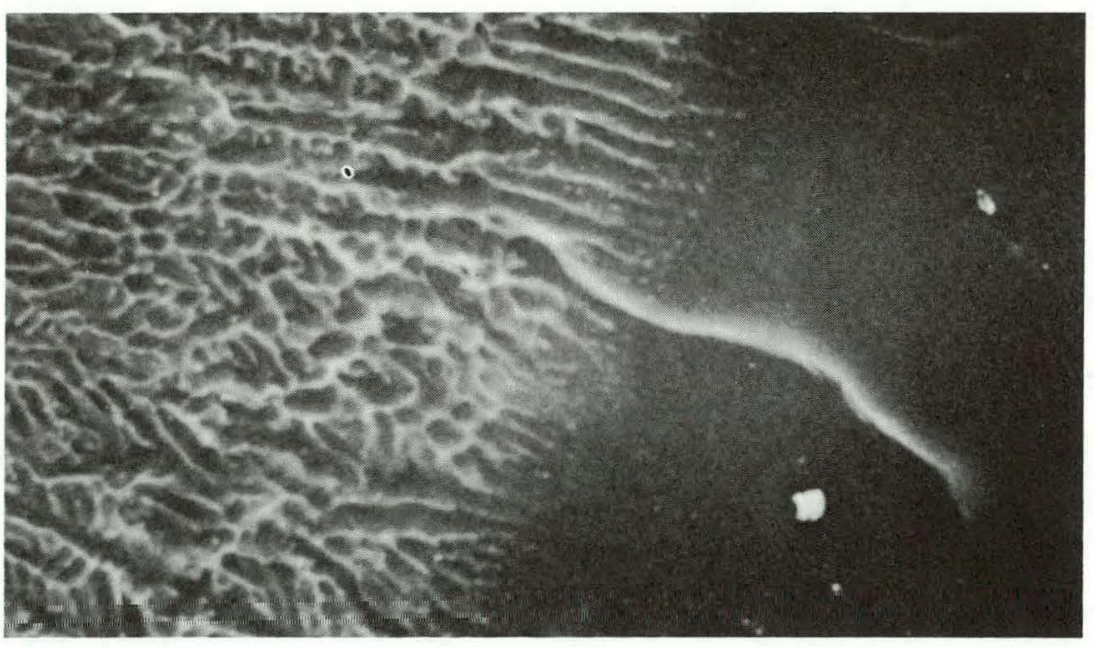

(b) At 1000X.

SM-63740

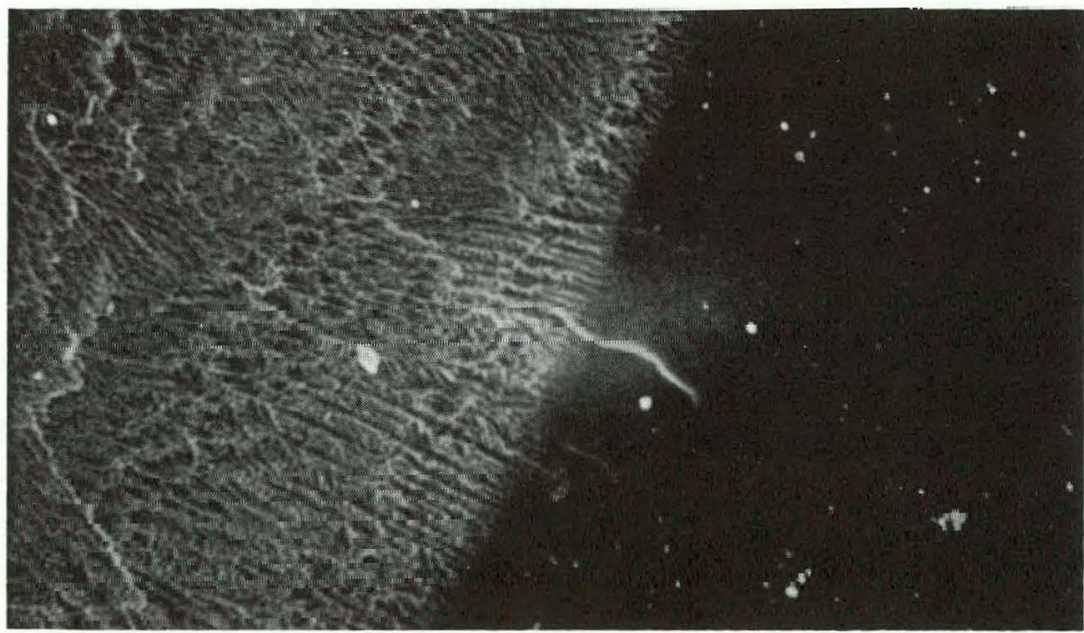

(c) At $300 \mathrm{X}$.

SM-63741

Figure 7. SCANNING ELECTRON MICROSCOPE EVALUATION OF A LIQUATED GRAIN BOUNDARY THAT EXTENDS INTO THE HEAT-AFFECTED ZONE. 
Since a satisfactory set of parameters was developed with the three sets of rings (four sets had been allocated to parameter development), Ring 4A (Joint Design 1, Figure 1), was welded to explore the range of penetration from 1.7 to $3.0 \mathrm{~mm}$. Figure 8 is a graph of these data. Also included are the pertinent sets of parameters from the previous rings. Again, the beam deflection was set in the aforementioned manner; and, also, a sharp focus was determined at the highest current used in each set of data and thereafter

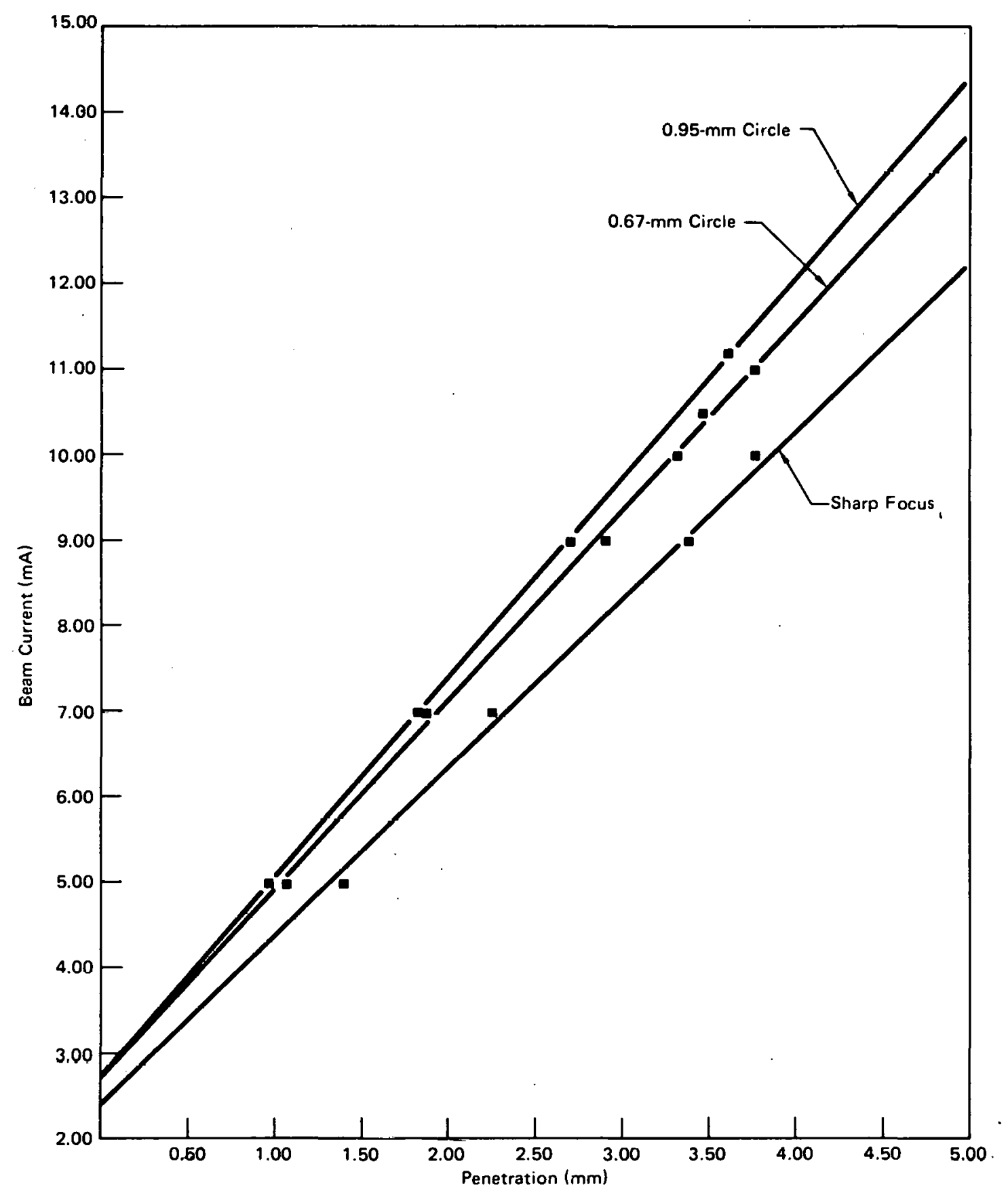

Figure 8. GRAPH OF BEAM CURRENT AS A FUNCTION OF PENETRATION FOR THREE DIFFERENT SPOT SIZES. (Parameters; $110 \mathrm{kV}, 8.1 \mathrm{~mm} / \mathrm{sec}$, Sharp Focus, $999 \mathrm{cps}$ Beam Oscillation) 
remained constant. As Figure 8 reveals, a good correlation was obtained between beam current, penetration, and spot size. These parameters, however, did not always result in the most desirable surface condition or fusion-zone shape.

\section{PARAMETER TUNING}

Prior to beginning the evaluation of welds made with the set of parameters developed in the first part of this study; the weld joint was redesigned (Joint Design 2, Figure 1). This change was dictated by two considerations: First, two conditions must exist for microcracking to occur: (1) an amenable microstructure and (2) sufficient strain. The presence of prior microcracking indicated that the necessary microstructure was present; thus, microcracking would result with the application of sufficient strain. To reduce this strain, the length of the step was increased so that the shrinkage stresses could be more readily accommodated. Second, the sharp corner at the step was replaced with a radius to reduce the stress concentration at this location. The rings incorporating this joint design were designated Rings 1B through 4B.

The first set of rings (Ring 1B) were welded to further tune the final parameters previously listed. Since the size of the circle being used for welding, and its reproducibility, was felt to be the most critical parameter, it was the parameter chosen for evaluation on this set of rings. Table 2 lists the circle sizes that were evaluated and the penetration results. As noted in Table 2, the penetration decreased as the circle size increased.

To further evaluate the effects of variations in circle size, transverse-weld-metal tensile specimens were tested (Figure 9).

Table 2

\begin{tabular}{ccc}
\multicolumn{2}{l}{ PENETRATION RESULTS OF PARAMETER TUNING } \\
\hline $\begin{array}{c}\text { Parameter } \\
\text { Set }\end{array}$ & $\begin{array}{c}\text { Circle Size } \\
\text { (mm D) }\end{array}$ & Penetration \\
\hline 1 & 0.76 & $\begin{array}{l}\bar{x}=4.29 \mathrm{~mm} \\
1 \sigma= \pm 0.16\end{array}$ \\
2 & 0.95 & $\begin{array}{l}\bar{x}=3.98 \mathrm{~mm} \\
1 \sigma= \pm 0.09\end{array}$ \\
3 & 1.14 & $\begin{array}{l}\bar{x}=3.83 \mathrm{~mm} \\
1 \sigma= \pm 0.38\end{array}$ \\
\hline
\end{tabular}
Since the variations in circle size resulted in variations in the aluminum content of the fusion zone, tensilc tests were used to determine if this variation affected the strength of the welds. These data are presented in Tables 3 and 4 . All but one specimen exhibited a base-metal failure.

The presence of aluminum, which made possible the braze-welding technique, prevented conventional heat-treating or chemical-etching procedures in the preparation of tensile specimens; therefore, the specimens were tested in the as-machined condition. The surface damage to the specimens caused by machining resulted in considerable scatter in the data. Thus, what may appear to be trends in the data, as well as the low values of the measured tensile properties when compared to the base-metal properties (Table 1), were due to the scatter in the data resulting from specimen preparation.

Table 5 lists the tensile-test results of the full-joint-geometry specimens (Figure 10) from Parameter Set 2, Ring 1B. As can be seen in Figure 10, these specimens were specifically 
designed to eliminate any bending moment on the weld during testing. These tests were made to evaluate this specimen design for future use, and the design proved to be satisfactory.
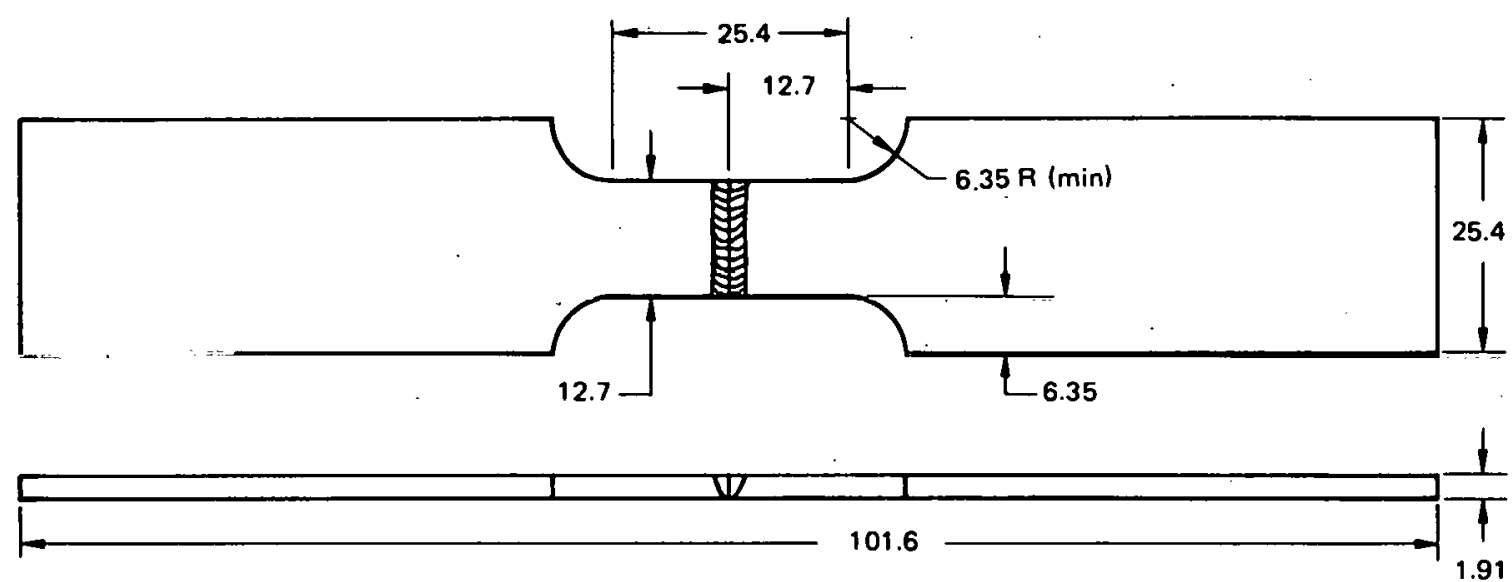

Figure 9. DIMENSIONS AND DESIGN OF THE TRANSVERSE-WELD-METAL TENSILE SPECIMENS. (AII Dimensions are in $\mathrm{mm}$ )

Table 3

TENSILE-TEST RESULTS OF TRANSVERSE-WELD-METAL SPECIMENS (FIGURE 9) FROM RING $1 \mathrm{~B}$

(Specimens Tested at a Strain Rate of $0.005 \mathrm{~mm} / \mathrm{mm} / \mathrm{min}$ )

\begin{tabular}{|c|c|c|c|c|c|}
\hline $\begin{array}{c}\text { Parameter } \\
\text { Set }\end{array}$ & $\begin{array}{l}\text { Specimen } \\
\text { Number }\end{array}$ & $\begin{array}{c}\text { Tensile } \\
\text { Strength } \\
\text { (MPa) }\end{array}$ & $\begin{array}{c}\text { Yield } \\
\text { Strength(1) } \\
\text { (MPa) }\end{array}$ & $\begin{array}{c}\text { Elongation }(2) \\
(\%)\end{array}$ & $\begin{array}{l}\text { Location } \\
\text { of } \\
\text { Failure (3) }\end{array}$ \\
\hline \multirow[t]{4}{*}{1} & 1.1 & 217.2 & - & 0.36 & $B M$ \\
\hline & $2-1$ & 227.5 & 222.0 & 0.46 & BM \\
\hline & 3-1 & 235.1 & 220.0 & 0.44 & BM \\
\hline & $\bar{x}$ & 226.6 & 221.0 & 0.42 & \\
\hline$\cdot$ & $1 \sigma$ & 9.0 & 1.4 & 0.05 & \\
\hline \multirow[t]{4}{*}{2} & $3-2$ & 164.1 & $\cdot \cdot$ & - & HAZ \\
\hline & $4-2$ & 246.8 & $\cdot$ & 0.36 & $\mathrm{BM}$ \\
\hline & $\bar{x}$ & 205.5 & . & - & \\
\hline & $1 \sigma$ & 58.0 & - & $\cdot$ & \\
\hline \multirow[t]{5}{*}{3} & 2.3 & 183.4 & . & 0.33 & BM \\
\hline & 3.3 & 154.4 & - & 0.38 & $B M$ \\
\hline & 4.3 & 232.4 & 219.3 & 0.40 & BM \\
\hline & $\bar{x}$ & 190.1 & - & 0.37 & \\
\hline & 10 & 39.4 & . & 0.04 & \\
\hline
\end{tabular}

(1) At a $0.2 \%$ offset.

(2) In $25.4 \mathrm{~mm}$.

(3) $\mathrm{BM}$ - base metal; HAZ - heat-affected zone.

\section{PARAMETER REPRODUCIBILITY}

Rings $2 \mathrm{~B}$ through $4 \mathrm{~B}$ were welded to evaluate the reproducibility of the weld parameters and to obtain distortion data. The final parameters resulted in penetrations which were remarkably consistent for the three rings that averaged $3.70 \mathrm{~mm}$, with a standard 
Table 4 (Specimens Tested at a Strain Rate of $0.2 \mathrm{~mm} / \mathrm{mm} / \mathrm{min}$ )

\begin{tabular}{|c|c|c|c|c|c|}
\hline $\begin{array}{l}\text { Parameter } \\
\text { Set }\end{array}$ & $\begin{array}{l}\text { Specimen } \\
\text { Number }\end{array}$ & $\begin{array}{c}\text { Tensile } \\
\text { Strength } \\
\text { (MPa) }\end{array}$ & $\begin{array}{c}\text { Yield } \\
\text { Strength(1) } \\
\text { (MPa) }\end{array}$ & $\begin{array}{c}\text { Elongation (2) } \\
(\%)\end{array}$ & $\begin{array}{l}\text { Location } \\
\text { of } \\
\text { Failure }^{(3)}\end{array}$ \\
\hline \multirow{5}{*}{1} & $4 \cdot 1$ & 221.3 & \multirow{5}{*}{261.3} & 0.11 & $B M$ \\
\hline & 5.1 & 267.5 & & 0.42 & $B M$ \\
\hline & $6-1$ & 242.5 & & 0.26 & BM \\
\hline & $\bar{x}$ & 243.8 & & 0.26 & \\
\hline & 10 & 23.1 & & 0.16 & \\
\hline \multirow[t]{4}{*}{2} & $5-2$ & 150.3 & - & - & $B M$ \\
\hline & 6-2 & 171.0 & - & - & BM \\
\hline & $\bar{x}$ & 160.7 & - & - & \\
\hline & 10 & 14.6 & - & - & \\
\hline \multirow[t]{4}{*}{3} & & 163.4 & - & & BM \\
\hline & $6-3$ & 189.6 & - & 0.14 & BM \\
\hline & $\bar{x}$ & 176.5 & $\therefore$ & & \\
\hline & 10 & 18.5 & $\cdot$ & - & \\
\hline
\end{tabular}

Table 5

TENSILE-TEST RESULTS OF FULL-JOINT-GEOMETRY SPECIMENS

(Results are Based on the Load-Bearing Cross Section of the Specimens)

\begin{tabular}{|c|c|c|c|c|c|}
\hline $\begin{array}{l}\text { Parameter } \\
\text { Set }\end{array}$ & $\begin{array}{l}\text { Specimen } \\
\text { Number }\end{array}$ & $\begin{array}{c}\text { Tensile } \\
\text { Strength } \\
\text { (MPa) }\end{array}$ & $\begin{array}{c}\text { Yield } \\
\text { Strength (1) } \\
\text { (MPa) }\end{array}$ & $\begin{array}{c}\text { Elongation (2) } \\
(\%)\end{array}$ & $\begin{array}{l}\text { Location } \\
\text { of } \\
\text { Failure (3) }\end{array}$ \\
\hline \multicolumn{6}{|c|}{ Strain Rate of $0.005 \mathrm{~mm} / \mathrm{mm} / \mathrm{min}$} \\
\hline \multirow[t]{6}{*}{2} & $7-2$ & 234.4 & . & 0.09 & BM \\
\hline & $8-2$ & 186.8 & - & 0.05 & $B M$ \\
\hline & $\frac{9-2}{\bar{y}}$ & 204.8 & . & 0.08 & \\
\hline & $\overline{\bar{x}}$ & 208.7 & & 0.07 & \\
\hline & $1 \sigma$ & 24.0 & - & 0.02 & \\
\hline & \multicolumn{5}{|c|}{ Strain Rate of $0.2 \mathrm{~mm} / \mathrm{mm} / \mathrm{min}$} \\
\hline \multirow{4}{*}{2} & $11-2$ & 140.0 & . & . & $B M$ \\
\hline & $12-2$ & 151.7 & . & & BM \\
\hline & $\overline{\mathrm{x}}$ & 145.9 & & - & \\
\hline & 10 & 8.3 & & & \\
\hline
\end{tabular}

(1) At $0.2 \%$ offset

(3) BM - base metal.
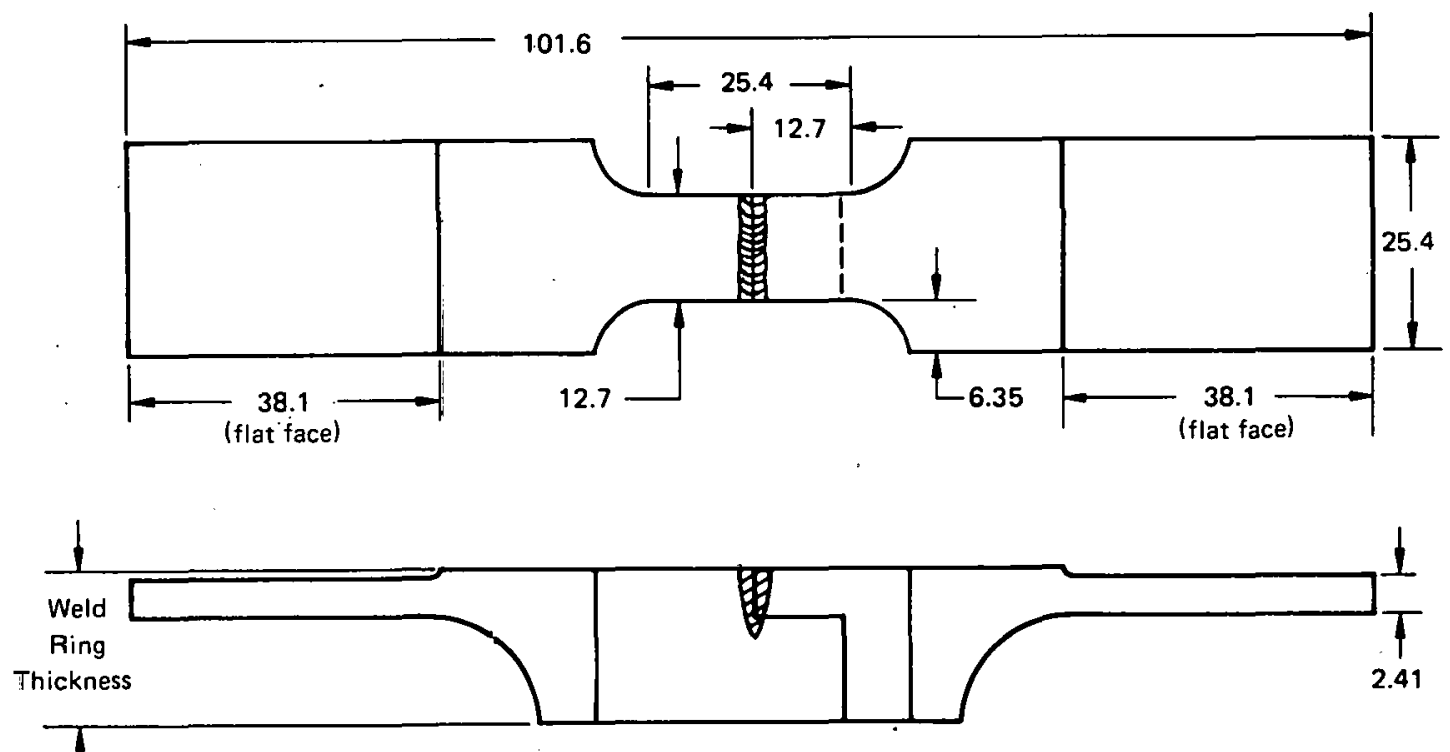

Figure 10. DIMENSIONS AND DESIGN OF THE FULL-JOINT-GEOMETRY TENSILE SPECIMENS. (AA Dimensions are in $\mathrm{mm}$ )

Table 6

SUMMATION OF DIAMETRAL SHRINKAGE DATA FROM RINGS $2 B$ THROUGH 4 (SSe Figure 11 for Data-Point Locations)

\begin{tabular}{|c|c|c|c|c|c|c|c|c|c|c|c|c|c|c|c|c|}
\hline & & & & & & & & ata $\mathrm{P}$ & & & & & & & & \\
\hline $\begin{array}{l}O C^{(1)} \\
\text { IC }\end{array}$ & 18 & $\begin{array}{l}17 \\
19\end{array}$ & 16 & $\begin{array}{l}15 \\
17\end{array}$ & $\begin{array}{l}14 \\
16\end{array}$ & $\begin{array}{l}13 \\
15\end{array}$ & 12 & 11 & 10 & 9 & 8 & 7 & 6 & 5 & 4 & 3 \\
\hline
\end{tabular}

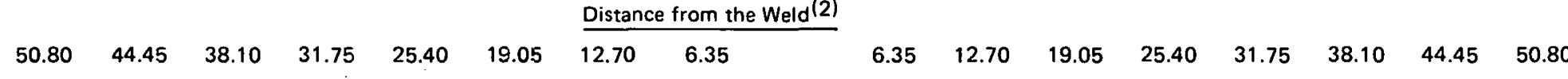
Ring 2B

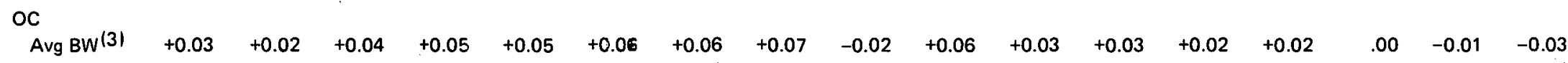
$\begin{array}{llllllllllllllllll}\text { Avg BW(31) } & +0.03 & +0.02 & +0.04 & +0.05 & +0.05 & +0.06 & +0.06 & +0.07 & -0.02 & +0.06 & +0.03 & +0.03 & +0.02 & +0.02 & .00 & -0.01 & -0.03 \\ \text { Avg AW } & -0.04 & -0.03 & -0.05 & -0.04 & -0.04 & -0.07 & -0.06 & -0.06 & -0.03 & -0.04 & -0.04 & -0.02 & -0.01 & +0.01 & +0.02 & +0.04 & +0.04 \\ \Delta D & -0.07 & -0.05 & -0.09 & -0.09 & -0.09 & -0.13 & -0.12 & -0.13 & +0.05 & -0.10 & -0.07 & -0.05 & -0.03 & -0.01 & +0.02 & +0.05 & +0.07\end{array}$ $\begin{array}{lllllllllllllllllll}{ }^{\mathrm{IC}} \mathrm{Avg} \mathrm{BW} & -0.04 & -0.03 & -0.01 & -0.03 & -0.03 & -0.03 & -0.02 & -0.03 & -0.03 & +0.01 & .00 & -0.02 & -0.02 & -0.04 & -0.07 & -0.08 & -0.10\end{array}$

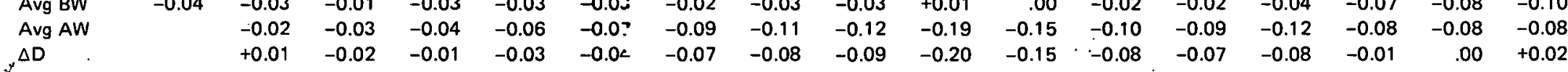
Ring 3B

$\begin{array}{llllllllllllllllll}\text { OC } \\ \text { Avg BW } & -0.05 & -0.02 & -0.02 & +0.01 & +0.01 & +0.05 & +0.04 & +0.05 & -0.03 & -0.03 & -0.04 & -0.05 & -0.05 & -0.05 & -0.06 & -0.07 & -0.08 \\ \text { Avg AW } & -0.02 & -0.04 & -0.05 & -0.06 & -0.08 & -0.15 & -0.12 & -0.19 & -0.07 & -0.09 & -0.05 & -0.05 & -0.03 & -0.03 & -0.02 & -0.02 & -0.02\end{array}$

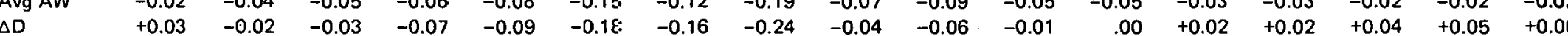
$\begin{array}{llllllllllllllllll}\text { IC } \\ \text { Avg BW } & -0.08 & -0.05 & -0.04 & -0.02 & -0.01 & -0.01 & .00 & +0.01 & +0.01 & +0.03 & -0.01 & -0.01 & -0.02 & -0.03 & -0.04 & -0.06 & -0.08 \\ \text { AD AW } & -0.0 & -0.05 & -0.06 & -0.4 & -0.10 & -0.12 & -0.0 & -0.16 & -0.19 & -0.25 & -0.0 & -0.08 & -0.04 & -0.04 & -00 & -0.03 & +0.06\end{array}$ $\begin{array}{llllllllllllllllll}\text { Avg AW } & -0.10 & -0.10 & -0.10 & -0.14 & -0.11 & -0.11 & -0.19 & -0.15 & -0.18 & -0.22 & -0.10 & -0.09 & -0.06 & -0.07 & -0.04 & -0.03 & -0.02 \\ \Delta \mathrm{D} & -0.02 & -0.05 & -0.06 & -0.12 & -0.10 & -0.15 & -0.19 & -0.16 & -0.19 & -0.25 & -0.09 & -0.08 & -0.04 & -0.04 & .00 & +0.03 & +0.06\end{array}$ Ring 4B

$\begin{array}{cccccccccccccccccc}\text { OC } & \\ \text { Avg BW } & -0.07 & -0.06 & -0.03 & -0.03 & +0.01 & +0.0 \Sigma & +0.04 & +0.05 & -0.16 & .00 & +0.01 & +0.01 & .00 & +0.01 & .00 & +0.01 & +0.01\end{array}$ $\begin{array}{lllllllllllllllllll}A v g & \\ \text { Avg AW } & -0.07 & +0.03 & +0.01 & -0.01 & -0.02 & -0.04 & -0.06 & -0.09 & -0.10 & -0.05 & -0.07 & -0.08 & -0.04 & -0.04 & -0.03 & -0.04 & -0.04 & -0.06 \\ \triangle \mathrm{D} & +0.10 & +0.07 & +0.02 & +0.01 & -0.05 & -0.05 & -0.13 & -0.15 & +0.11 & -0.07 & -0.09 & -0.05 & -0.04 & -0.04 & -0.04 & -0.05 & -0.07\end{array}$ $\begin{array}{llllllllllllllllll}\text { IC } \\ \text { Avg BW } & -0.13 & -0.11 & -0.08 & -0.05 & -0.04 & .00 & -0.01 & .00 & +0.01 & +0.01 & +0.02 & -0.03 & -0.03 & -0.04 & -0.04 & -0.04 & -0.04 \\ \text { Avg AW } & -0.13 & -0.12 & -0.11 & -0.11 & -0.16 & -0.16 & -0.12 & -0.19 & -0.15 & -0.15 & -0.10 & -0.13 & -0.13 & -0.08 & -0.10 & -0.06 & -0.07\end{array}$ $\begin{array}{lrlllllllllllllllll}\text { Avg AW } & -0.13 & -0.12 & -0.11 & -0.11 & -0.16 & -0.1 \epsilon & -0.12 & -0.19 & -0.15 & -0.15 & -0.10 & -0.13 & -0.13 & -0.08 & -0.10 & -0.06 & -0.07 \\ \Delta D & .00 & -0.01 & -0.03 & -0.06 & -0.12 & -0.1 \epsilon & -0.11 & -0.19 & -0.16 & -0.16 & -0.12 & -0.10 & -0.10 & -0.04 & -0.06 & -0.02 & -0.03\end{array}$ Three-Ring Composite

\begin{tabular}{|c|c|c|c|c|c|c|c|c|c|c|c|c|c|c|c|c|c|}
\hline$\overline{\bar{x}} \Delta \mathrm{D}$ & +0.02 & .00 & -0.03 & -0.05 & -0.08 & -0.13 & -0.14 & -0.17 & +0.04 & -0.07 & -0.05 & -0.03 & -0.01 & -0.01 & -0.01 & +0.02 & +0.03 \\
\hline 10 & 0.08 & 0.06 & 0.06 & 0.05 & 0.03 & 0.05 & 0.02 & 0.06 & 0.08 & 0.02 & 0.04 & 0.03 & 0.03 & 0.03 & 0.04 & 0.04 & 0.07 \\
\hline$\overline{\mathrm{x}}$ & -0.01 & -0.02 & -0.04 & -0.06 & -009 & $-0.1 c$ & -0.12 & -0.15 & -0.15 & -020 & -0.12 & -009 & $-0,07$ & -0.05 & -0.02 & +001 & +0.02 \\
\hline$\hat{11}$ & 002 & 0.03 & 0.7 & 0.00 & 000 & 006 & 006 & 006 & 005 & 0.04 & 0.03 & 000 & 0.03 & 0.02 & 0.03 & 0.03 & 0.04 \\
\hline
\end{tabular}

(1) OC - outside contour; IC - inside contour.

(3) $B W$ - before welding; $A W$ - after welding; $\Delta D$ - change in diameter. 
deviation of $\pm 0.16 \mathrm{~mm}$. These three welds also had an average aluminum content of $26.3 w t \%$, with a standard deviation of $\pm 1.2 \mathrm{wt} \%$.

Axial and diametral shrinkage data were also obtained from Rings $2 \mathrm{~B}$ through $4 \mathrm{~B}$. In an attempt to induce weld cracking and to test the joint design, Rings $2 \mathrm{~B}$ through $4 \mathrm{~B}$ were welded over a tight backing ring. The backgaps (the gap in the backside of the step joint) on Rings $3 \mathrm{~B}$ and $4 \mathrm{~B}$ were shimmed to provide minimal clearance. Cracking was not detected either visually or radiographically in any of the rings. Also, the results of axial shrinkage from these rings were inconclusive. Ring 2B, which had an open backgap, averaged $0.15 \mathrm{~mm}$ of axial shrinkage; while Rings $3 \mathrm{~B}$ and $4 \mathrm{~B}$, which had "no" backgaps, exhibited 0.11 and $0.19 \mathrm{~mm}$ of axial shrinkage, respectively. The diametral shrinkage observed on these three rings is summarized in Table 6, with Figure 11 showing the

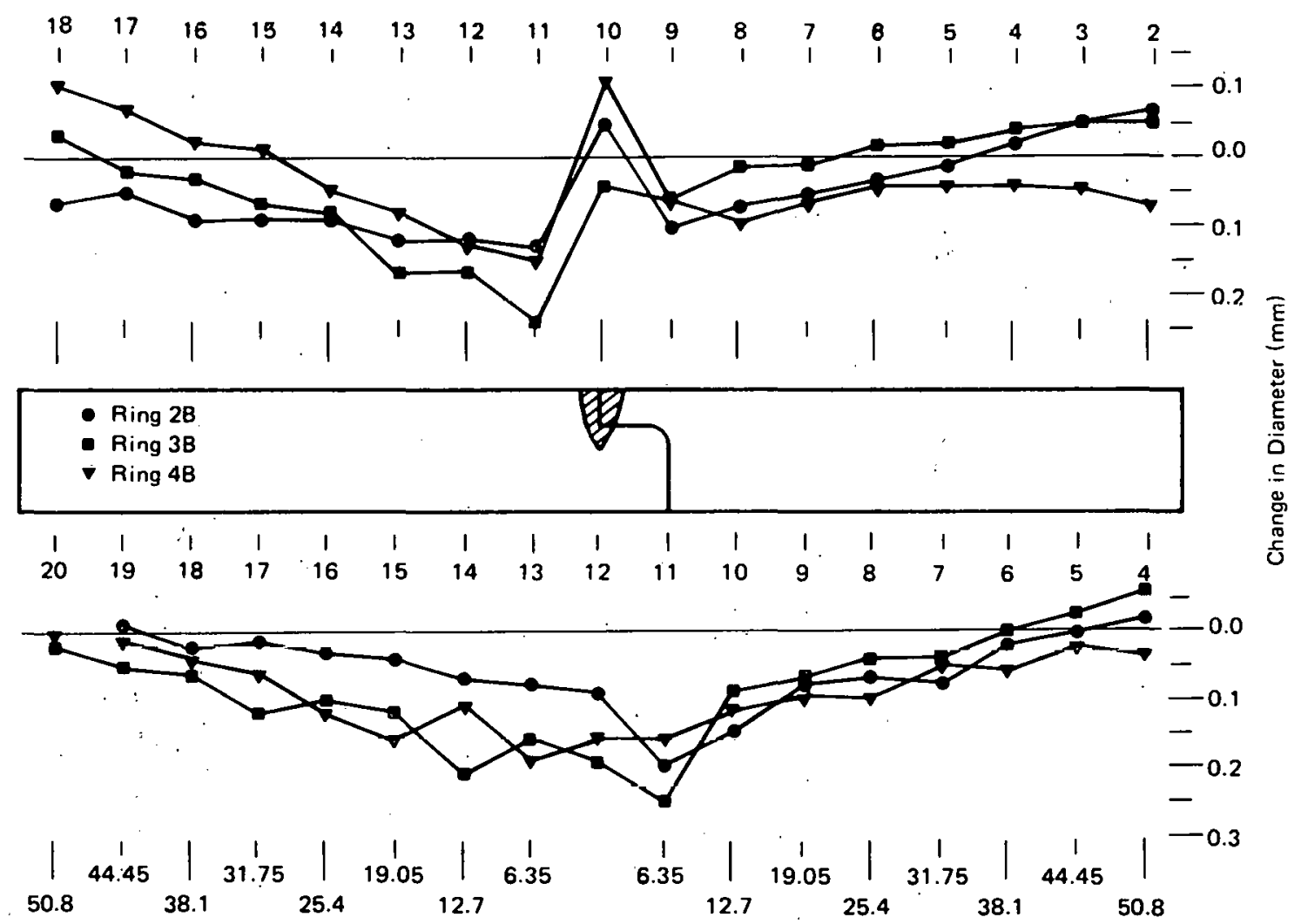

Figure 11. CHANGE IN DIAMETĖR AS A FUNCTION OF THE DISTANCE FROM THE WELD FOR RINGS 2B THROUGH 4B.

location of the data points and giving a graphic presentation of the data. Since all three welds were made over a tight backing ring, the diametral shrinkage was moderate, but did follow a predictable pattern.

Finally, the tensile-test results of the full-joint-geometry specimens from Rings $2 \mathrm{~B}$ through $4 \mathrm{~B}$ are summarized in Tables 7 through 9 . Improved machining removed much of the scatter in the data, and the data are very consistent. All of the failures were in the 
Table 7

TENSILE-TEST RESULTS OF FULL-JOINT-GEOMETRY SPECIMENS

(FIGURE 10) FROM RING $2 B$

(Results are Based on the Load-Bearing Cross Section)

\begin{tabular}{|c|c|c|c|c|c|c|c|}
\hline $\begin{array}{l}\text { Specimen } \\
\text { Location }\end{array}$ & $\begin{array}{l}\text { Specimen } \\
\text { Number }(1)\end{array}$ & I. & $\begin{array}{l}\text { Tensite } \\
\text { Strength } \\
\text { (MPa) }\end{array}$ & $\begin{array}{l}\text { Yield } \\
\text { Strength }(2) \\
\text { (MPa). }\end{array}$ & $\begin{array}{c}\text { Elongation (3) } \\
(\%)\end{array}$ & . & $\begin{array}{l}\text { Location } \\
\text { of } \\
\text { Failure }^{(4)}\end{array}$ \\
\hline \multirow[t]{3}{*}{$0^{\circ}$} & 1 & & 266.2 & 211.0 & 0.44 & & $\mathrm{BM}$ \\
\hline & 2 & : & 254.4 & $\cdot \quad \cdot$ & 0.08 & & BM \\
\hline & 3 & & 226.8 & . & 0.07 & & $B M$ \\
\hline \multirow[t]{3}{*}{$90^{\circ}$} & 1 & & 295.8 & 207.0 & 0.29 & & BM \\
\hline & 2 & & 250.4 & - & 0.09 & & $B M$ \\
\hline & 3 & & .254 .4 & - & 0.09 & & BM \\
\hline \multirow[t]{3}{*}{$180^{\circ}$} & 1 & & $\ldots$ & • &. & & - \\
\hline & 2 & & 264.2 & 252.4 & $0.3 i$ & & BM \\
\hline & 3 & & 307.6 & 191.3 & 0.69 & & BM \\
\hline \multirow[t]{3}{*}{$270^{\circ}$} & 1 & & 246.5 & - & 0.09 & & $B M$ \\
\hline & 2 & & 262.3 & - & 0.19 & & $\mathrm{BM}$ \\
\hline & 3 & & 238.6 & 197.2 & 0.32 & & $B M$ \\
\hline $\bar{x}$ & $\therefore$ & & 260.7 & 211.8 & 0.24 & & \\
\hline 10 & & & 23.5 & 24.0 & 0.20 & & \\
\hline
\end{tabular}

(1) These specimens were tested at a constant rate $(1.27 \mathrm{~mm} / \mathrm{min})$ of crosshead travel.

(2) At a $0.2 \%$ offset.

(3) In $25.4 \mathrm{~mm}$.

(4) BM - base metal.

Table 8

TENSILE-TEST RESULTS OF FULL-JOINT-GEOMETRY SPECIMENS

(FIGURE 10) FROM RING 3B

(Results are Based on the Load-Bearing Cross Section)

\begin{tabular}{|c|c|c|c|c|c|c|}
\hline $\begin{array}{l}\text { Specimen } \\
\text { Location }\end{array}$ & $\begin{array}{l}\text { Specimen } \\
\text { Number (1) }\end{array}$ & $\begin{array}{l}\text { Tensile } \\
\text { Strength } \\
\text { (MPa) }\end{array}$ & $\begin{array}{c}\text { Yield } \\
\text { Strength (2) } \\
\text { (MPa) }\end{array}$ & $\begin{array}{c}\text { Elongation }(3) \\
(\%)\end{array}$ & & $\begin{array}{l}\text { Location } \\
\text { of } \\
\text { Failure }\end{array}$ \\
\hline \multirow[t]{3}{*}{$0^{\circ}$} & 1 & 262.3 & - & 0.09 & & $B M$ \\
\hline & 2 & 246.5 & - & 0.08 & & $B M$ \\
\hline & 3 & 264.2 & - & 0.09 & & BM \\
\hline \multirow[t]{3}{*}{$90^{\circ}$} & 1 & 266.2 & - & 0.10 & & BM \\
\hline & 2 & 246.5 & - & 0.08 & & BM \\
\hline & 3 & 230.7 & - & 0.07 & & $B M$ \\
\hline \multirow[t]{3}{*}{$180^{\circ}$} & 1 & 232.7 & - & 0.04 & & BM \\
\hline & 2 & 246.5 & - & 0.08 & - & $B M$ \\
\hline & 3 & 264.2 & - & 0.10 & & $B M$ \\
\hline \multirow[t]{3}{*}{$270^{\circ}$} & 1 & 272.1 & - & 0.11 & & BM \\
\hline & 2 & 256.3 & - & 0.09 & & BM \\
\hline & 3 & 248.5 & - & 0.08 & & $B M$ \\
\hline $\bar{x}$ & & 253.1 & $\therefore$ & 0.08 & & \\
\hline $1 \sigma$ & & 13.3 & - & 0.02 & . & \\
\hline
\end{tabular}

(1) These specimens were tested at a constant rate $(1.27 \mathrm{~mm} / \mathrm{min})$ of crosshead travel.

(2) At a $0.2 \%$ offset.

(3) $\ln 25.4 \mathrm{~mm}$.

(4) BM - base metal. 
Table 9

TENSILE-TEST RESULTS OF FULL-JOINT.GEOMETRY SPECIMENS

(FIGURE 10) FROM RING $4 B$

(Results are Based on the Load-Bearing Cross Section)

\begin{tabular}{cccccc}
\hline $\begin{array}{c}\text { Specimen } \\
\text { Location }\end{array}$ & $\begin{array}{c}\text { Specimen } \\
\text { Number(1) }\end{array}$ & $\begin{array}{c}\text { Tensile } \\
\text { Strength } \\
\text { (MPa) }\end{array}$ & $\begin{array}{c}\text { Yield } \\
\text { Strength(2) } \\
\text { (MPa) }\end{array}$ & $\begin{array}{c}\text { Location } \\
\text { Elongation (3) } \\
\text { (\%) }\end{array}$ & $\begin{array}{c}\text { of } \\
\text { Failure (4) }\end{array}$ \\
\hline 00 & 1 & 280.0 & - & 0.10 & BM \\
& 2 & 278.0 & - & 0.10 & BM \\
900 & 3 & 280.0 & - & 0.10 & BM \\
& 1 & 254.4 & - & 0.10 & BM \\
1800 & 2 & 242.5 & - & 0.14 & BM \\
& 3 & 262.3 & - & 0.09 & BM \\
& 1 & 236.6 & - & 0.06 & BM \\
2700 & 2 & 244.5 & - & 0.06 & BM \\
& 3 & 254.4 & - & 0.08 & BM \\
& 1 & 218.9 & - & 0.05 & BM \\
$\bar{X}$ & 2 & 266.2 & - & 0.10 & BM \\
10 & 3 & 268.2 & - & 0.10 & \\
\hline
\end{tabular}

(1) These specimens were tested at a constant rate $(1.27 \mathrm{~mm} / \mathrm{min})$ of crosshead travel.

(2) At a $0.2 \%$ offset.

(3) $\ln 25.4 \mathrm{~mm}$.

(4) BM - base metal.

base metal; however, testing as-machined specimens meant that the $1 \%$ minimum ductility of the base metal was not realized. Whether or not the results would have been the same if the higher ductility were realized in the base metal cannot be answered. 


\section{REFERENCES}

1. Passmore, E. M.; "Fusion Welding of Beryllium", The Welding Journal, 43, (3), Research Supplement, pp 116-S - 125-S (1964).

2. Pumphrey, W. I. and Jennings, P. H.; "A Consideration of the Nature of Brittleness at Temperatures Above the Solidus in Castings and Welds in Aluminum Alloys", Journal of the Institute of Metals, 75, pp 235 - 256 (1948).

3. Pellini, W. S.; "Strain Theory of Hot Tearing", Foundry, 80, (11), pp $125-133$ (1952).

4. Apblett, W. R. and Pellini, W. S.; "Factors Which Influence Weld Hot Cracking", The Welding Journal, 33 (2), Research Supplement, pp 83-S - 90-S (1954).

5. Borland, J. C.; "Generalized Theory of Super-Solidus Cracking in Welds land Castings)", The British Welding Journal, 7 (8), pp 508 - 512 (1961).

6. Borland, J. C.; "Suggested Explanation of Hot Cracking in Mild and Low Alloy Steel Welds", The British Welding Journal, 8 (11), pp 526 - 540 (1961).

7. Gilliland, R. G. and Slaughter, G. M.; "Fusion Welding End Gaps in Beryllium Tubes", The Welding Journal, 42, (1), pp 29 - 36 (1963).

8. Hauser, D., et al ; "Electron Beam Welding of Beryllium", The Welding Journal, 46 (12), Research Supplement, pp 525-S - 540-S (1967).

9. Hicken, G. K. and Sample, W. B., Jr; "Joining Beryllium by an Electron Beam Braze Welding "Technique", The Welding Journal, 46, (12), Research Supplement, pp 540-S - 550-S (1967).

10. Ibid; p 550-S.

11. Corel, Richard R.; "Summary of Beryllium Specification", RFP-2664, p 3; Rockwell International-Atomics International Division; February 17, 1978. 


\section{ACKNOWLEDGEMENTS}

The author wishes to acknowledge the cooperation of G. P. Howard, RockwellInternational, Rocky Flats Plant, in the procurement and fabrication of the beryllium weld rings; to D. T. Cook, Y-12 Alpha-5 East Machine Shop, for his concern and attention in the preparation of tensile specimens; to C. A. Reeves, Jr, Y-12 Physical Testing, for his aid in testing the tensile specimens, and to M. E. Garrison, Y-12 Metallurgy Department, for his assistance in preparing this report. Finally, the author wishes to extend special credit to the Lawrence Livermore Laboratory for funding this study. 


\section{Distribution}

Department of Energy - Oak Ridge

Hickman, H. D.

Leed, R. E.

Zachry, D. S., Jr

Lawrence Livermore Laboratory

Armstrong, R. E.

Mara, G. L.

Nelson, W. E.

Los Alamos Scientific Laboratory

Hoyt, H. C.

Monsanto-Mound Laboratory

McDougal, J. R.

Oak Ridge Gaseous Diffusion Plant

Stief, S. S.

Wilcox, W. J., Jr

Oak Ridge National Laboratory

Goodwin, G. M.

Slaughter, G. M.

Weir, J. R., Jr

Oak Ridge $Y-12$ Plant

Alvey, H. E.

Armstrong, R. C.

Bernander, N, $K$.

Bieber, C. R.

Burditt, R. B.

Cook, D. T.

Cuddy, L. M.

Dodson, W. H./Googin, J. M.

Dritt, W. S.

Duggan, H. G.

Fraser, R. J.

Frye, L. D.

Garrison, M. E.

Gritzner, V. B.

Haeusler, K. R.

Huber, R. A.
Jackson, V. C.

Jessen, N. C., Jr

Jones, F. W.

Kahl, K. G.

Keith, A.

Kite, H. T.

Koger, J.W.

Kollie, T. G.

Masor, D. L./Schreyer, J. M.

Mills, J. M., Jr

Murphy, J. L.

Parrott, N. R.

Perkins, M. A. (25)

Phillips, L. R.

Reeves, C. A., Jr

Scott, D. G.

Smith, H. F., Jr

Smith, R. D.

Stoner, H. H.

Tewes, W. E.

Tilson, F. V.

$Y-12$ Central Files (master copy)

$Y-12$ Central Files (route copy)

$Y-12$ Central Files ( $Y-12 R C)$

$Y-12$ Central Files (10)

Zava, A. K.

Paducah Gaseous Diffusion Plant

Bewley, H. D.

Union Carbide Corporation - New York

Tinsley, S. W.

In addition, this report is distributed in accordance with the Category UC-38, Engineering and Equipment, as given in the USERDA Standard Distribution Lists for Unclassified Scientific and Technical Reports, TID-4500. 